Cardiology in the Young

http://journals.cambridge.org/CTY

Additional services for Cardiology in the Young:

Email alerts: $\underline{\text { Click here }}$

Subscriptions: $\underline{\text { Click here }}$

Commercial reprints: Click here

Terms of use : $\underline{\text { Click here }}$

\title{
A family with a new elastin gene mutation: broad clinical spectrum, including sudden cardiac death
}

André Jakob, Sheila Unger, Raoul Arnold, Jochen Grohmann, Cornelia Kraus, Christian Schlensak and Brigitte Stiller

Cardiology in the Young / Volume 21 / Issue 01 / February 2011, pp 62 - 65

DOI: 10.1017/S1047951110001563, Published online: 16 November 2010

Link to this article: http://journals.cambridge.org/abstract S1047951110001563

How to cite this article:

André Jakob, Sheila Unger, Raoul Arnold, Jochen Grohmann, Cornelia Kraus, Christian Schlensak and Brigitte Stiller (2011). A family with a new elastin gene mutation: broad clinical spectrum, including sudden cardiac death. Cardiology in the Young, 21, pp 62-65 doi:10.1017/S1047951110001563

Request Permissions : $\underline{\text { Click here }}$ 


\title{
A family with a new elastin gene mutation: broad clinical spectrum, including sudden cardiac death
}

\author{
André Jakob, ${ }^{1}$ Sheila Unger, ${ }^{2}$ Raoul Arnold, ${ }^{1}$ Jochen Grohmann, ${ }^{1}$ Cornelia Kraus, ${ }^{3}$ Christian Schlensak, ${ }^{4}$ \\ Brigitte Stiller ${ }^{1}$ \\ ${ }^{1}$ Department of Pediatric Cardiology, University Hospital of Freiburg, Mathildenstraße 1; ${ }^{2}$ Department of Human \\ Genetics, University Hospital of Freiburg, Breisacherstraße 33, 79106 Freiburg; ${ }^{3}$ Department of Human Genetics, \\ University Hospital of Erlangen, Schwabachanlage 10, 91054 Erlangen; ${ }^{4}$ Department of Cardiac Surgery, \\ University Hospital of Freiburg, Hugstetter Street 5579106 Freiburg, Germany
}

\begin{abstract}
Supravalvular aortic stenosis is associated with the Williams-Beuren syndrome, but it also occurs in a non-syndromatic congenital form. An elastin gene mutation of chromosome $7 \mathrm{q} 11.23$ is responsible in both cases. The vascular features are identical. These patients have a higher risk of sudden death, particularly when undergoing diagnostic or surgical procedures. We report the account of a family with a new mutation in the elastin gene. Screening over three generations revealed eight affected individuals. The cardiac and vascular malformations ranged from mild asymptomatic supravalvular aortic stenosis and isolated dysplastic atrioventricular valves to diffuse arterial hypoplasia. Two infants presented arteries affected at multiple locations, including the left coronary artery. Both died of sudden cardiac death and myocardial ischaemia, one while under general anaesthesia for cardiac catheterisation, and the other perioperatively. We discuss the pathophysiological aspects in these patients that deserve consideration before any general anaesthesia is administered.
\end{abstract}

Keywords: Supravalvular aortic stenosis; general anaesthesia; coronary stenoses

Received: 20 May 2010; Accepted: 22 August 2010; First published online: 16 November 2010

$\mathrm{S}$ UPRAVALVULAR AORTIC STENOSIS IS A RARE FORM OF left cardiac obstruction. Most of such patients suffer from the Williams-Beuren syndrome. Non-syndromatic, congenital supravalvular aortic stenosis, which lacks the cognitive, behavioural, and phenotypic abnormalities of the Williams-Beuren syndrome, is less common. However, it is known that alterations in the arterial vessels in both illnesses are due to an elastin gene mutation. ${ }^{1-3}$ This gene is located on chromosome $7 \mathrm{q} 11.23$, and it is inherited in an autosomal-dominant trait. ${ }^{1,4-6}$ In the Williams-Beuren syndrome, deletion of one complete copy of the elastin gene is identified. ${ }^{7}$ In non-syndromatic supravalvular aortic stenosis, there are several mechanisms involving

Correspondence to: Dr A. Jakob, Department of Pediatric Cardiology, University Hospital of Freiburg, Mathildenstraße 1, 79106 Freiburg, Germany. Tel: +49(0)761 270 4323; Fax: +49(0)761 270 4468; E-mail: andre.jakob@ uniklinik-freiburg.de the elastin gene, such as point mutations, ${ }^{5,8-12}$ translocations, ${ }^{1,13}$ and gross intragenic deletion. ${ }^{6,14}$ The other manifestation of the Williams-Beuren syndrome is encoded by other genes, for example, defects in visuospatial cognition are thought to be caused by the loss of one allele of LIM domain kinase $1 .^{15,16}$ The vascular features are manifold. Aortic narrowing is often described as an hourglass deformity with discrete constriction, but it can also occur as diffuse arterial hypoplasia. It is characteristically associated with peripheral pulmonary artery stenosis, such as supravalvular pulmonary stenosis. Biventricular hypertrophy resulting from increased resistance is followed by a progressive clinical course, worsening in patients with coronary artery involvement. There are several reports of sudden cardiac death $^{17-19}$ and it is generally acknowledged that these patients are at higher risk when undergoing diagnostic or surgical procedures. ${ }^{20}$ In our institution, two patients not known to be related suffered 


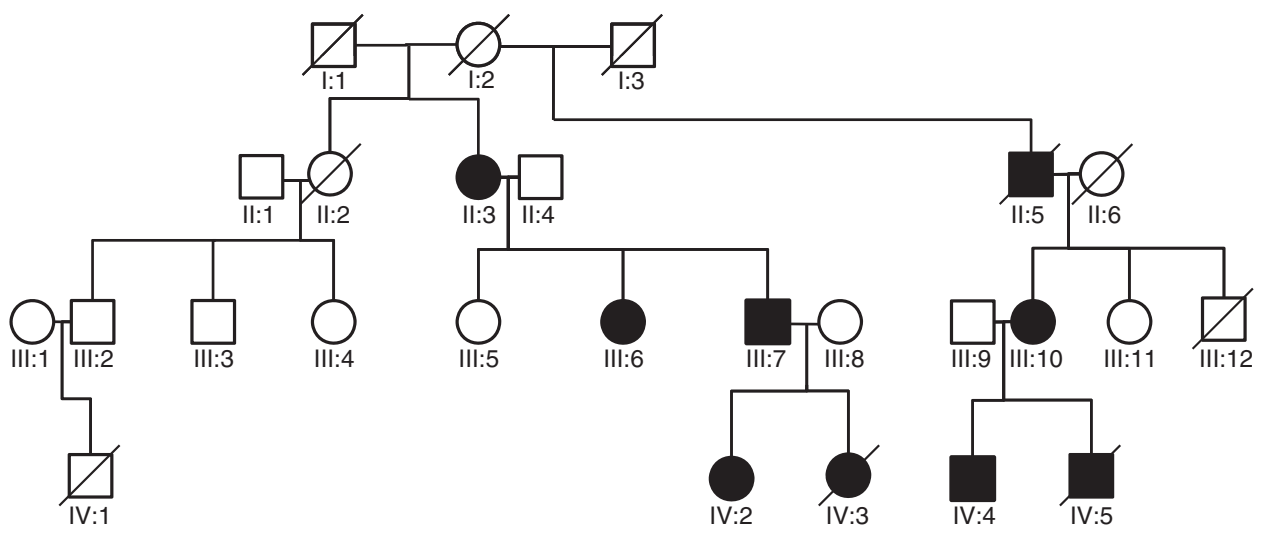

Figure 1.

Pedigree of a family with elastin gene mutation. Eight individuals are affected and present with different phenotypic expression.

cardiac arrest, requiring resuscitation while under general anaesthesia for catheterisation. One died during catheterisation, the other shortly after surgical repair. We screened the family and identified eight patients with a new point mutation in the elastin gene. We describe the various vascular disorders in this family, as well as the deceased infants' clinical course.

\section{Materials and methods}

We investigated three generations of a family of Caucasian origin. Direct sequencing analysis of genomic amplifiers was used to screen the 33 elastin gene exons for mutation. Polymerase chain reaction fragments were automatically analysed (ABI 3730, Applied Biosystems, Foster City, California, United States of America). All sequences were evaluated using the Sequence Pilot Software (JSI Medical Systems) and matched with the reference sequences (NT_007758, NM_000501). The cardiac and vascular malformations in these patients were determined by echocardiogram, and angiographically in two patients. One patient was autopsied; thus we had access to macroscopic and histological aspects regarding anatomical vascular abnormalities.

\section{Results}

\section{Elastin gene mutation}

We identified a single base-pair mutation in the elastin gene, a deletion of cytosine at position 757 in exon 15. This mutation is predicted to cause a glutamine-to-arginine replacement at position 253 and a frame shift with a premature stop-codon (the mutant allele encodes a 68 amino-acid longmissense peptide sequence). This sequence change has been previously described but given the nature of the mutation and its segregation within the family, it is almost certainly pathogenic.

\section{Cardiovascular features}

Eight individuals in this family over three generations are affected by diverse phenotypic expressions (see Fig 1). Two family members have isolated supravalvular aortic stenosis. III:10 has a very mild form, III:6 underwent surgical repair at the age of 11 years. III:7 is the only individual with isolated peripheral pulmonary stenosis, diagnosed at the age of 8 years due to a systolic murmur. He has remained asymptomatic so far. Individuals II:5 and IV:4 have isolated dysplastic aortic valves with mild stenosis. IV:2 suffers from isolated pulmonary valve stenosis.

IV:5 was a 9-month-old boy who died during cardiac catheterisation in 1997. At the age of 7 months he underwent cardiac surgery with patch augmentation of the aortic and pulmonary stenosis and excision of the fibrous tissue, narrowing the left coronary artery ostium. He was discharged home, and presented 5 weeks after surgery in our clinic with increasing hyperventilation, sweating, and exhaustion. Electrocardiography revealed ST-segment depression, and echocardiography showed poor ventricular function. Angiography was therefore performed and showed severe stenosis of the left coronary artery. The child unfortunately died during catheterisation of left ventricular failure due to coronary stenosis. Autopsy revealed all the great arterial vessels to be thickwalled, including the coronary artery. Histological investigation revealed the three layers of the arteries to be hypertrophic with reduced elastin content in the media, smooth muscle proliferation, and fibrosis. Textural changes in the elastin and collagen fibres also affected the pulmonary valve.

IV:3 was a 5-month-old girl with an initial diagnosis of supravalvular aortic stenosis, supravalvular pulmonary stenosis, aortic coarctation, and biventricular hypertrophy. By the age of 3 months she presented with recurrent, rapidly recompensating syncopes. Her relationship to IV:5 was not known at that time. During the induction of anaesthesia for 
diagnostic catheterisation, she suddenly developed cardiac decompensation. After successful resuscitation and haemodynamic stabilisation, we performed angiography with contrast injection into the left ventricle, additionally revealing a hypoplastic left coronary artery and hypoplastic abdominal aorta. After numerous life-threatening syncopes, we carried out surgical reconstruction of the aortic arch. Cardiopulmonary bypass weaning failed, and a pulsatile left ventricular assistance device (MEDOS Medizintechnik AG, Stollenberg, Germany) was implanted. Nevertheless, the infant died several hours later of biventricular heart failure. An autopsy was not performed.

\section{Discussion}

\section{Elastin gene and morphological features}

Elastin is an essential component of the great arteries. Several elastin gene mutations have been reported. ${ }^{1,5,6,8-14}$ We have detected a new single basepair mutation in the elastin gene. The molecular sequence conducting from loss-of-function mutation to supravalvular aortic stenosis has been investigated in humanised elastin mice. ${ }^{21}$ This study illustrates that reconstituting functional elastic fibres corrects the existing cardiovascular changes in elastin haploinsufficient mice. The deletion on the elastin gene leads to reduced elastin content in the medial layer of the arteries, which may be followed by recurrent injury and fibrosis. Microscopically, the involved vessels reveal disorganised, fragmented elastic fibres of reduced quantity, hypertrophied smooth muscle cells, and excessive collagen. ${ }^{18,22}$ The postmortem examination of one deceased infant with multi-focal arterial obstruction revealed the same histopathological disarrangements in all the affected arteries. The pulmonary valve is also included here in these histological changes, not yet having caused any clinical valve dysfunction. There are few reports of the semilunar valves having been affected in this disease. One report describes the aortic valve leaflets to be partially adherent to the stenosing supravalvular ridge in more than half of the patients. ${ }^{23}$ Echocardiographically, three of our family members (II:5, IV:5, and IV:2) only have dysplastic semilunar valves with mild stenosis, with no evidence of stenotic vessels.

In our family, the vasculopathies thereby range from localised stenosis of the ascending aorta to diffuse obstruction affecting the entire aorta, including the origin of the head and neck vessels; ${ }^{24}$ the pulmonary arteries are also commonly affected. ${ }^{25}$ Disease severity varies and does not depend on elastin gene mutation. The cardiopathic variability within one family is as great as that among individuals with different elastin gene mutations. ${ }^{10}$ As in our family, the clinical spectrum varies from asymptomatic carriers to individuals who die in infancy from severe cardiac disease. ${ }^{5}$

\section{Sudden cardiac death}

Disease severity, especially clinical progress, may be strongly affected by coronary artery involvement. Significant coronary artery involvement in patients with supravalvular aortic stenosis has been described. ${ }^{26}$ Coronary artery stenosis occurs as focal or diffuse narrowing of the vessel itself, or it can be due to obstruction by redundant dysplastic aortic valve leaflets. ${ }^{23,27}$ In our family with supravalvular aortic stenosis, infants IV:5 and IV:3 presented narrowing of the left coronary artery. The increased risk for sudden cardiac death may be accompanied by coronary stenosis. Bird et al. ${ }^{17}$ reported three cases of Williams-Beuren syndrome patients with sudden cardiac death and a displacement of the coronary ostia superior to a position just below the sinotubular ridge with subsequent obstruction. Even without haemodynamically significant supravalvular aortic stenosis, cases of coronary stenosis have been reported. ${ }^{17,18,22,28-31}$ The diastolic component of phasic coronary blood flow also depends on aortic distensibility, referred to as the "Windkessel effect". Reduced elastic fibres and increased fibrosis lead to aortic stiffening, which in turn raises systolic and reduces diastolic pressure ${ }^{32}$ (thus lowering coronary blood flow).

Biventricular obstruction also leads to ventricular pressure overload, and secondarily to myocardial hypertrophy with a prolonged ejection and highpressure isovolumic contraction phase. Subendocardial ischaemia can easily develop in such patients. In particular, the administration of anaesthesia in conjunction with a sudden drop in the afterload may well alter this delicate balance between myocardial oxygen supply and demand.

Several series and case reports have described sudden death in association with the administration of sedative or anaesthetic drugs for cardiac catheterisation or surgical, cardiac or non-cardiac, procedures. ${ }^{17,33-35}$ Sudden cardiac death correlated with the presence of coronary artery obstruction in most of the affected patients.

Any application of general anaesthesia should undergo careful scrutiny and only be performed by well-experienced anaesthesiologists anticipating such problems. Alternatives for invasive diagnosis should be carefully considered. For example, cardiac magnetic resonance imaging appears to be an increasingly promising non-invasive imaging modality capable of delineating blood flow obstruction. ${ }^{36}$ 


\section{Acknowledgement}

We wish to thank Carole Cürten, Medical editor, for editorial assistance.

\section{References}

1. Curran ME, Atkinson DL, Ewart AK, Morris CA, Leppert MF, Keating MT. The elastin gene is disrupted by a translocation associated with supravalvular aortic stenosis. Cell 1993; 73: 159-168.

2. Ewart AK, Morris CA, Ensing GJ, et al. A human vascular disorder, supravalvular aortic stenosis, maps to chromosome 7. Proc Natl Acad Sci U S A 1993; 90: 3226-3230.

3. Rodriguez-Revenga L, Badenas C, Carrio A, Mila M. Elastin mutation screening in a group of patients affected by vascular abnormalities. Pediatr Cardiol 2005; 26: 827-831.

4. Morris CA. Genetic aspects of supravalvular aortic stenosis. Curr Opin Cardiol 1998; 13: 214-219.

5. Metcalfe K, Rucka AK, Smoot L, et al. Elastin: mutational spectrum in supravalvular aortic stenosis. Eur $\mathrm{J}$ Hum Genet 2000; 8: 955-963.

6. Ewart AK, Jin W, Atkinson D, Morris CA, Keating MT. Supravalvular aortic stenosis associated with a deletion disrupting the elastin gene. J Clin Invest 1994; 93: 1071-1077.

7. Wu YQ, Sutton VR, Nickerson E, et al. Delineation of the common critical region in Williams syndrome and clinical correlation of growth, heart defects, ethnicity, and parental origin. Am J Med Genet 1998; 78: 82-89.

8. Boeckel T, Dierks A, Vergopoulos A, et al. A new mutation in the elastin gene causing supravalvular aortic stenosis. Am J Cardiol 1999; 83: 1141-1143; A9-A10.

9. Dedic J, Weiss AS, Katahira J, Yu B, Trent RJ, Urban Z. A novel elastin gene mutation (1281delC) in a family with supravalvular aortic stenosis: a mutation cluster within exon 20. Hum Mutat 2001; $17: 81$.

10. Li DY, Toland AE, Boak BB, et al. Elastin point mutations cause an obstructive vascular disease, supravalvular aortic stenosis. Hum Mol Genet 1997; 6: 1021-1028.

11. Tassabehji M, Metcalfe K, Donnai D, et al. Elastin: genomic structure and point mutations in patients with supravalvular aortic stenosis. Hum Mol Genet 1997; 6: 1029-1036.

12. Urban Z, Michels VV, Thibodeau SN, Donis-Keller H, Csiszar K, Boyd CD. Supravalvular aortic stenosis: a splice site mutation within the elastin gene results in reduced expression of two aberrantly spliced transcripts. Hum Genet 1999; 104: 135-142.

13. von Dadelszen $\mathrm{P}$, Chitayat $\mathrm{D}$, Winsor EJ, et al. De novo $46, \mathrm{XX}, \mathrm{t}(6 ; 7)(\mathrm{q} 27 ; \mathrm{q} 11 ; 23)$ associated with severe cardiovascular manifestations characteristic of supravalvular aortic stenosis and Williams syndrome. Am J Med Genet 2000; 90: 270-275.

14. Olson TM, Michels VV, Urban Z, et al. A $30 \mathrm{~kb}$ deletion within the elastin gene results in familial supravalvular aortic stenosis. Hum Mol Genet 1995; 4: 1677-1679.

15. Tassabehji M, Metcalfe K, Fergusson WD, et al. LIM-kinase deleted in Williams syndrome. Nat Genet 1996; 13: 272-273.

16. Frangiskakis JM, Ewart AK, Morris CA, et al. LIM-kinase1 hemizygosity implicated in impaired visuospatial constructive cognition. Cell 1996; 86: 59-69.

17. Bird LM, Billman GF, Lacro RV, et al. Sudden death in Williams syndrome: report of ten cases. J Pediatr 1996; 129: 926-931.

18. Conway EE Jr, Noonan J, Marion RW, Steeg CN. Myocardial infarction leading to sudden death in the Williams syndrome: report of three cases. J Pediatr 1990; 117: 593-595.
19. Wessel A, Gravenhorst V, Buchhorn R, Gosch A, Partsch CJ, Pankau R. Risk of sudden death in the Williams-Beuren syndrome. Am J Med Genet A 2004; 127A: 234-237.

20. Pham PP, Moller JH, Hills C, Larson V, Pyles L. Cardiac catheterization and operative outcomes from a multicenter consortium for children with Williams syndrome. Pediatr Cardiol 2009; 30: 9-14.

21. Hirano E, Knutsen RH, Sugitani H, Ciliberto CH, Mecham RP. Functional rescue of elastin insufficiency in mice by the human elastin gene: implications for mouse models of human disease. Circ Res 2007; 101: 523-531.

22. van Son JA, Edwards WD, Danielson GK. Pathology of coronary arteries, myocardium, and great arteries in supravalvular aortic stenosis. Report of five cases with implications for surgical treatment. J Thorac Cardiovasc Surg 1994; 108: 21-28.

23. Stamm C, Li J, Ho SY, Redington AN, Anderson RH. The aortic root in supravalvular aortic stenosis: the potential surgical relevance of morphologic findings. J Thorac Cardiovasc Surg 1997; 114: 16-24.

24. Vaideeswar P, Shankar V, Deshpande JR, Sivaraman A, Jain N. Pathology of the diffuse variant of supravalvar aortic stenosis. Cardiovasc Pathol 2001; 10: 33-37.

25. Eronen M, Peippo M, Hiippala A, et al. Cardiovascular manifestations in 75 patients with Williams syndrome. J Med Genet 2002; 39: 554-558.

26. Stamm C, Friehs I, Ho SY, Moran AM, Jonas RA, del Nido PJ. Congenital supravalvar aortic stenosis: a simple lesion? Eur J Cardiothorac Surg 2001; 19: 195-202.

27. Matsuda H, Miyamoto Y, Takahashi T, Kadoba K, Nakano S, Sano T. Extended aortic and left main coronary angioplasty with a single pericardial patch in a patient with Williams syndrome. Ann Thorac Surg 1991; 52: 1331-1333.

28. Terhune PE, Buchino JJ, Rees AH. Myocardial infarction associated with supravalvular aortic stenosis. J Pediatr 1985; 106: 251-254.

29. van Pelt NC, Wilson NJ, Lear G. Severe coronary artery disease in the absence of supravalvular stenosis in a patient with Williams syndrome. Pediatr Cardiol 2005; 26: 665-667.

30. Bonnet D, Cormier V, Villain E, Bonhoeffer P, Kachaner J. Progressive left main coronary artery obstruction leading to myocardial infarction in a child with Williams syndrome. Eur J Pediatr 1997; 156: 751-753.

31. Geggel RL, Gauvreau K, Lock JE. Balloon dilation angioplasty of peripheral pulmonary stenosis associated with Williams syndrome. Circulation 2001; 103: 2165-2170.

32. Izzo JL Jr. Arterial stiffness and the systolic hypertension syndrome. Curr Opin Cardiol 2004; 19: 341-352.

33. Horowitz PE, Akhtar S, Wulff JA, Al Fadley F, Al Halees Z. Coronary artery disease and anesthesia-related death in children with Williams syndrome. J Cardiothorac Vasc Anesth 2002; 16: 739-741.

34. Bragg K, Fedel GM, DiProsperis A. Cardiac arrest under anesthesia in a pediatric patient with Williams syndrome: a case report. AANA J 2005; 73: 287-293.

35. Monfared A, Messner A. Death following tonsillectomy in a child with Williams syndrome. Int J Pediatr Otorhinolaryngol 2006; 70: 1133-1135.

36. Park JH, Kim HS, Jin GY, Joo CU, Ko JK. Demonstration of peripheral pulmonary stenosis and supravalvular aortic stenosis by different cardiac imaging modalities in a patient with Williams syndrome usefulness of noninvasive imaging studies. Int J Cardiol 2008; 128: e95-e97. 